mgr inz. Piotr Michalak,

mgr inz. Wojciech Jakuszko,

mgr inz. Mariusz Far

Instytut Pojazdów Szynowych ,TABOR”

\title{
Modern systems and assemblies in modernized 6Di and 19D locomotives
}

\author{
Nowoczesne uklady i zespoły \\ w modernizowanych lokomotywach typu 6Di i 19D
}

\begin{abstract}
The article is devoted to the presentation of modern systems and assemblies used in modernized shunting locomotives. The article presents the main parameters of locomotives before and after modernization. Three types of locomotives are described: 6Di with a Caterpillar engine, 6Di with a Cummins engine and 19D with an MTU engine.

The article also contains a number of information on the scope of locomotive modernization and traction characteristics.

Artykut jest poświęcony prezentacji nowoczesnych ukladów i zespołów zastosowanych $w$ modernizowanych lokomotywach manewrowych. W artykule przedstawiono glówne parametry lokomotyw przed i po modernizacji. Opisano trzy typy lokomotyw: $6 \mathrm{Di}$ z silnikiem Caterpillar, 6Di z silnikiem Cumminsa oraz 19D z silnikiem MTU.

Artykut zawiera ponadto szereg informacji o zakresie modernizacji lokomotyw oraz charakterystyki trakcyjne.
\end{abstract}

\section{Introduction}

Requirements currently imposed on new combustion traction vehicles set by applicable regulations and standards force rail operators to either purchase new rolling stock or modernize their existing rolling stock.

For many years, polonization of locomotives imported from abroad as well as remotorization of locomotives operated in the country have been performed. These activities were rather cosmetic in nature and did not significantly improve the technical level of often old and depleted locomotives. Only full modernization of the locomotives significantly increases their technical level along with having a positive effect on the natural environment.

Currently, the term deep/full modernization should be understood as the replacement of all major locomotive assemblies, leaving the chassis and bogies along with the drive and gearing systems, that are brought to their original state as a result of the repair.

In addition, it should be noted that the process of modernizing diesel locomotives is needed for several reasons:

- keeping up with the development of new technologies

- meeting the requirements of operators in terms of maintenance and operation

- balance between the technical level of owned and new locomotives

\section{Wstęp}

Wymagania jakie obecnie stawiane są nowym spalinowym pojazdom trakcyjnym określone obowiązującymi przepisami i normami wymuszają na przewoźnikach konieczność zakupu nowego taboru lub modernizację taboru istniejącego.

Przez wiele lat przeprowadzano polonizację lokomotyw sprowadzanych z zagranicy oraz remotoryzację lokomotyw eksploatowanych w kraju. Powyższe działania były raczej natury kosmetycznej i nie poprawiały w znaczący sposób poziomu technicznego często wyeksploatowanych lokomotyw. Dopiero głęboka modernizacja lokomotyw w istotny sposób podnosi poziom techniczny taboru a także wpływa korzystnie na środowisko naturalne.

Obecnie pod hasłem głębokiej/pełnej modernizacji należy rozumieć wymianę wszystkich głównych zespołów lokomotywy z pozostawieniem ostoi i wózków z układami napędowymi i biegowymi, które zostają w wyniku naprawy głównej doprowadzone do stanu pierwotnego.

Ponadto należy zaznaczyć, że proces modernizacji lokomotyw spalinowych wynika z kilku przesłanek:

- nadazzanie za postępującym rozwojem technicznym

- spełnienie wymagań użytkowników w zakresie utrzymania i eksploatacji

- równowaga pomiędzy poziomem technicznym lokomotyw posiadanych i nowych 
- higher requirements of drivers and service crews for older locomotives.

The goals set in the design and implementation stages expected by operators in relation to the modernized diesel locomotives are:

- reducing the consumption of diesel oil and lubricants

- limiting harmful impact on the natural environment, including reducing the share of toxic components in the exhaust gases, such as $\mathrm{CO}, \mathrm{HC}$, $\mathrm{NO}_{\mathrm{x}}$ and particulate matter

- reduction of $\mathrm{CO}_{2}$ emission

- increasing the number of operations between scheduled inspections and repairs

- use of modern and high durability devices, systems and units with extended service life

- limiting the emission of internal noise and magnetic field in drivers' cabs

- improvement of service comfort and safety in cabins by implementing modern desktop systems armchair, panoramic windows to improve visibility, use of air conditioning and social devices such as fridges or washbasins.

The Institute of Rail Vehicles TABOR has been developing modernization projects for the last few years for shunting locomotives such as the popular SM42 and TEM2/SM48. These projects have been implemented for specific users on the basis of detailed technical and operational requirements as well as applicable regulations and standards.

The first described modernization procedure concerns the SM42 series diesel locomotive (6D). Designed at CBK PTK in Poznan in the mid-fifties, it was produced by the Locomotive Factory in Chrzanów for over 30 years. In total, about 2,000 of these most popular locomotives were produced, of which about 1,200 for the needs of the PKP (Polish State Railways), 600 for industrial plants and 37 were exported to Morocco. The locomotives were designed for shunting and freight work and were equipped with $6 \mathrm{D}, 1 \mathrm{LN}$ and $1 \mathrm{LNa}$ bogies.

The second analyzed modernized diesel locomotive is SM48 (TEM2 in the industry). It is a single-cabin six-axle locomotive with an electric transmission designed for servicing eastern border regions in reloading, heavy maneuvering operations and after installing the Polish rail safety systems also for freight operations. The SM48 locomotive was prepared for works on tracks with a width of $1435 \mathrm{~mm}$ and 1520 $\mathrm{mm}$ and was imported to Poland from the former USSR since 1974 both for the needs of PKP and industrial railways. In total, 130 locomotives for PKP and 300 for mines, steelworks, mining plants and railway transport companies have been purchased.

\section{Locomotive 6Di - modernized locomotive of the SM42 series}

- coraz wyższe wymagania maszynistów i obsługi serwisowej w stosunku do lokomotyw starszych wiekiem.

Cele jakie stawiane są $\mathrm{w}$ pracach projektowowdrożeniowych oczekiwane przez użytkowników w stosunku do modernizowanych lokomotyw spalinowych to:

- zmniejszenie zużycia oleju napędowego i środków smarnych

- ograniczenie szkodliwego oddziaływania na środowisko naturalne w tym zmniejszenie udziału emisji do atmosfery składników toksycznych spalin takich jak $\mathrm{CO}, \mathrm{HC}, \mathrm{NO}_{\mathrm{x}}$ i cząstki stałe

- zmniejszenie wydzielania $\mathrm{CO}_{2}$ do atmosfery

- zwiększenie przebiegów eksploatacyjnych pomiędzy wykonywanymi przeglądami i naprawami

- zastosowanie nowoczesnych i trwałych aparatów, urządzeń i zespołów o wydłużonym czasie eksploatacji

- ograniczenie emisji hałasu wewnętrznego i pola magnetycznego w kabinach maszynistów

- poprawa komfortu obsługi i bezpieczeństwa w kabinach przez zastosowanie nowoczesnych układów pulpit - fotel, okien panoramicznych celem poprawienia widoczności, stosowania klimatyzacji i urządzeń socjalnych, takich jak lodówki lub umywalki.

Instytut Pojazdów Szynowych TABOR przez ostatnie kilka lat opracował projekty modernizacji m.in. lokomotyw manewrowych, takich jak popularne SM42 i TEM2/SM48. Wspomniane projekty zostały zrealizowane $\mathrm{z}$ myślą o konkretnych użytkownikach na podstawie szczegółowych wymagań technicznoeksploatacyjnych oraz obowiązujących przepisów i norm.

Pierwsza opisana modernizacja dotyczy lokomotywy spalinowej serii SM42 (6D). Zaprojektowana w CBK PTK w Poznaniu w połowie lat pięćdziesiątych była produkowana przez Fabrykę Lokomotyw w Chrzanowie przez ponad 30 lat. Ogółem wyprodukowano około 2000 sztuk tych najbardziej popularnych lokomotyw z czego około 1200 na potrzeby Polskich Kolei Państwowych, 600 sztuk dla zakładów przemysłowych, a 37 sztuk wyeksportowano do Maroka. Lokomotywy przeznaczone były do prowadzenia prac manewrowych i pracy liniowej $\mathrm{z}$ pociagiem towarowym i wyposażone były $\mathrm{w}$ wózki typu $6 \mathrm{D}, 1 \mathrm{LN}$ i $1 \mathrm{LNa}$.

Druga modernizowana lokomotywa spalinowa to SM48 (w przemyśle TEM2). Jest to jednokabinowa

\section{Lokomotywa 6Di - zmodernizowana lokomo- tywa serii SM42}

Lokomotywa spalinowa typu 6Di serii SM42 o układzie osi Bo-Bo przeznaczona jest przede wszystkim do prac manewrowych i przetokowych oraz prowadzenia lekki pociaggów towarowych na liniach. 
Diesel locomotive 6Di type series SM42 with the Bo-Bo axis system is intended primarily for shunting operations as well as running light freight lines on standard track lines at speeds of up to $90 \mathrm{~km} / \mathrm{h}$. The modernization process was carried out for two types of internal combustion engines. The 6Di locomotive with the CATERPILLAR C27 ACERT engine was built in 2015, while the 6Di locomotive with the CUMMINS QSK23 L-900 engine was built at the end of 2016. 6Di locomotives were built by PESA Bydgoszcz S.A.

The 6 Di locomotive project was designed with a modular construction in mind, which is why the main locomotive systems were built in self-supporting modules adapted for lifting by gantry for maintenance and repairs. The exception is the generator set module, where the motor with the generator has been mounted on the intermediate frame, while the module housing is an independently demountable structure.

A general overview of the layout of machines and devices is shown in Fig. 2.1, while Figures 2.2 and 2.3 show a detailed arrangement of devices on both types of 6Di locomotives. normalnotorowych z prędkością do $90 \mathrm{~km} / \mathrm{h}$. Proces modernizacji przeprowadzono dla dwóch typów silników spalinowych. W 2015 roku zbudowano lokomotywę 6Di z silnikiem CATERPILLAR C27 ACERT, natomiast w końcu roku 2016 zbudowano lokomotywę 6Di z silnikiem CUMMINS QSK23 L-900. Lokomotywy 6Di zostały zbudowane przez Pojazdy Szynowe PESA Bydgoszcz S.A..

Projekt lokomotyw 6Di zakładał budowę modułową, dlatego główne układy lokomotywy zostały zabudowane $\mathrm{w}$ samonośnych modułach przystosowanych do podnoszenia za pomocą suwnicy podczas prac serwisowych i napraw. Wyjątkiem jest moduł agregatu prądotwórczego, gdzie silnik $\mathrm{z}$ prądnicą został zamontowany na ramie pośredniej, natomiast obudowa modułu stanowi niezależnie demontowalną konstrukcję.

Widok ogólny rozplanowania maszyn i urządzeń przedstawiono na rys. 2.1 , natomiast na rys. $2.2 \mathrm{i}$ 2.3 widok szczegółowego rozmieszczenia urządzeń na obu typach lokomotyw 6Di.

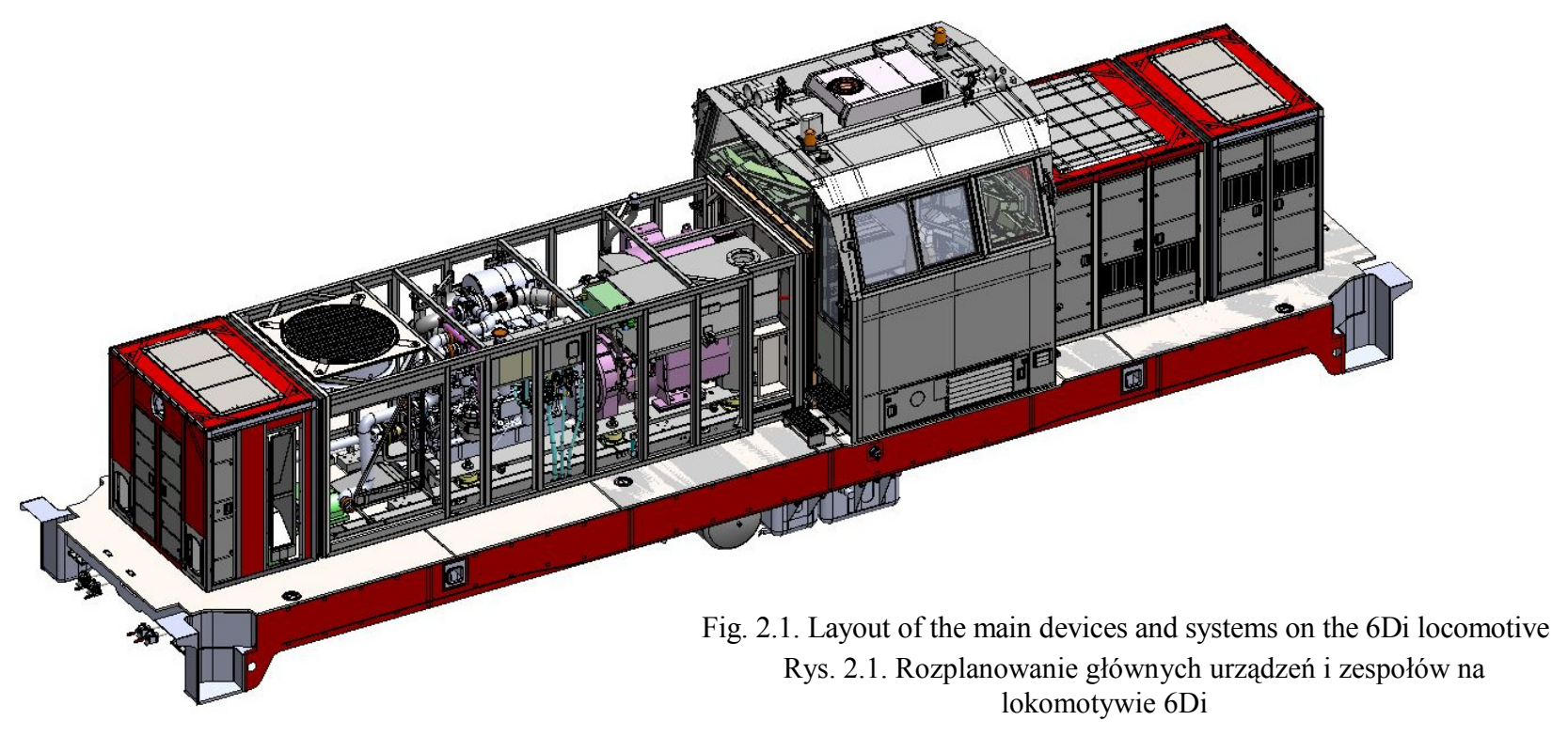

\subsection{The scope of $6 \mathrm{Di}$ locomotives modernization and technical parameters}

The modular construction of the 6Di locomotive made it possible to improve production and efficient preparation of construction and technical documentation. In the modernized locomotive, the chassis was retained, in which the deck sheet was changed into a new deck made of $25 \mathrm{~mm}$ sheet metal, which allowed to minimize the need for ballasting the locomotive and at the same time stiffened the supporting structure of the chassis. In addition, sand tanks for the locomotive equipped with $6 \mathrm{D}$ bogies were built into the chassis. In the case of $1 \mathrm{LN}$ and $1 \mathrm{LNa}$ bogies, sand tanks are built on bogies and the chassis does not require assembly.

\subsection{Zakres modernizacji i parametry techniczne lokomotyw 6Di}

Budowa modułowa lokomotywy 6Di pozwoliła na usprawnienie produkcji oraz sprawne przygotowanie dokumentacji konstrukcyjnej i technicznej. W modernizowanej lokomotywie zachowana została ostoja, w której zamieniono blachy pokładu na nowy pokład wykonany z $25 \mathrm{~mm}$ blachy, co pozwoliło na zminimalizowanie konieczności balastowania lokomotywy i jednocześnie usztywniło konstrukcję nośną ostoi. Ponadto $\mathrm{w}$ ostoi zabudowano zbiorniki piasku dla lokomotywy wyposażonej w wózki 6D. W przypadku stosowania wózków $1 \mathrm{LN}$ i $1 \mathrm{LNa}$ zbiorniki piasku zabudowane są na wózkach i ostoja nie wymaga ich montażu. 

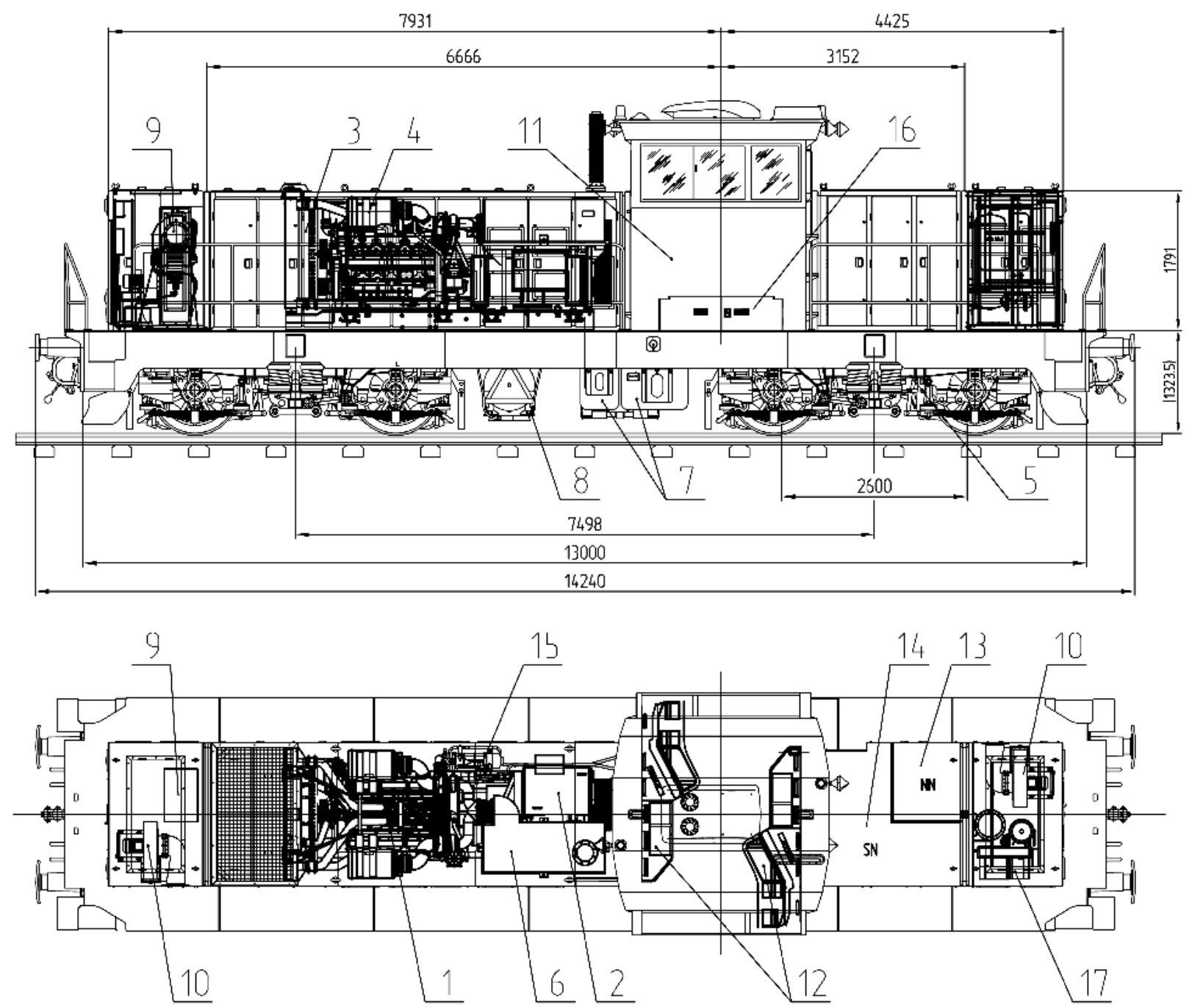

Fig. 2.2. Location of systems and devices on a type 6Di diesel locomotive of the SM42 series with CAT C27 engine (1 - combustion engine, 2 - synchronous generator set, 3 - cooler unit/fan, 4 - air filter,

5 - bogie, 6 - exhaust muffler, 7 - fuel tanks, 8 - electromagnet, 9 - compressor unit, 10 - traction motors fan, 11 driver's cab, 12 - control desks, 13 - LV cabinet, 14 - MV cabinet, 15 - Webasto heater, 16 - battery box, 17 pneumatic board).

Rys. 2.2. Rozmieszczenie maszyn i urządzeń na lokomotywie spalinowej typu 6Di serii SM42 z silnikiem CAT C27

(1 - silnik spalinowy, 2 - zespół prądnic synchronicznych, 3 - zespół chłodnic / wentylator, 4 - filtr powietrza, 5 wózek, 6 - tłumik wylotu spalin, 7 - zbiorniki paliwa, 8 - elektromagnes, 9 - agregat sprężarkowy, 10 - wentylator silników trakcyjnych, 11 - kabina maszynisty, 12 - pulpity sterownicze, 13 - szafa NN, 14 - szafa SN, 15 podgrzewacz Webasto, 16 - skrzynia akumulatorów, 17 - tablica pneumatyczna)

The main modernized and new systems and devices are:

- CATERPILLAR C27 ACERT or CUMMINS QSK 23 L-900 internal combustion engine, both engines meet the Stage IIIA emissions norms according to Directive 2004/26/EC

- generator set - main Ghp $400 \mathrm{M} 4 \mathrm{C}-1$ (for CAT engine) or Ghp 400 M4C-2 (for Cummins engine) with auxiliary generator Ghp 315 S4K

- pneumatic board

- compressor unit with screw compressor driven by an $\mathrm{AC}$ motor
Główne zmodernizowane i nowe układy oraz urządzenia to:

- silnik spalinowy CATERPILLAR typu C27 ACERT lub CUMMINS QSK 23 L-900, oba silniki spełniaja poziom emisji substancji szkodliwych - etap IIIA wg dyrektywy 2004/26/WE

- zespół prądnic - główna Ghp 400 M4C-1 (dla silnika CAT) lub Ghp 400 M4C-2 (dla silnika Cummins) z prądnicą pomocniczą Ghp 315 S4K

- tablica pneumatyczna

- agregat sprężarkowy ze sprężarką śrubową napędzaną silnikiem prądu przemiennego 

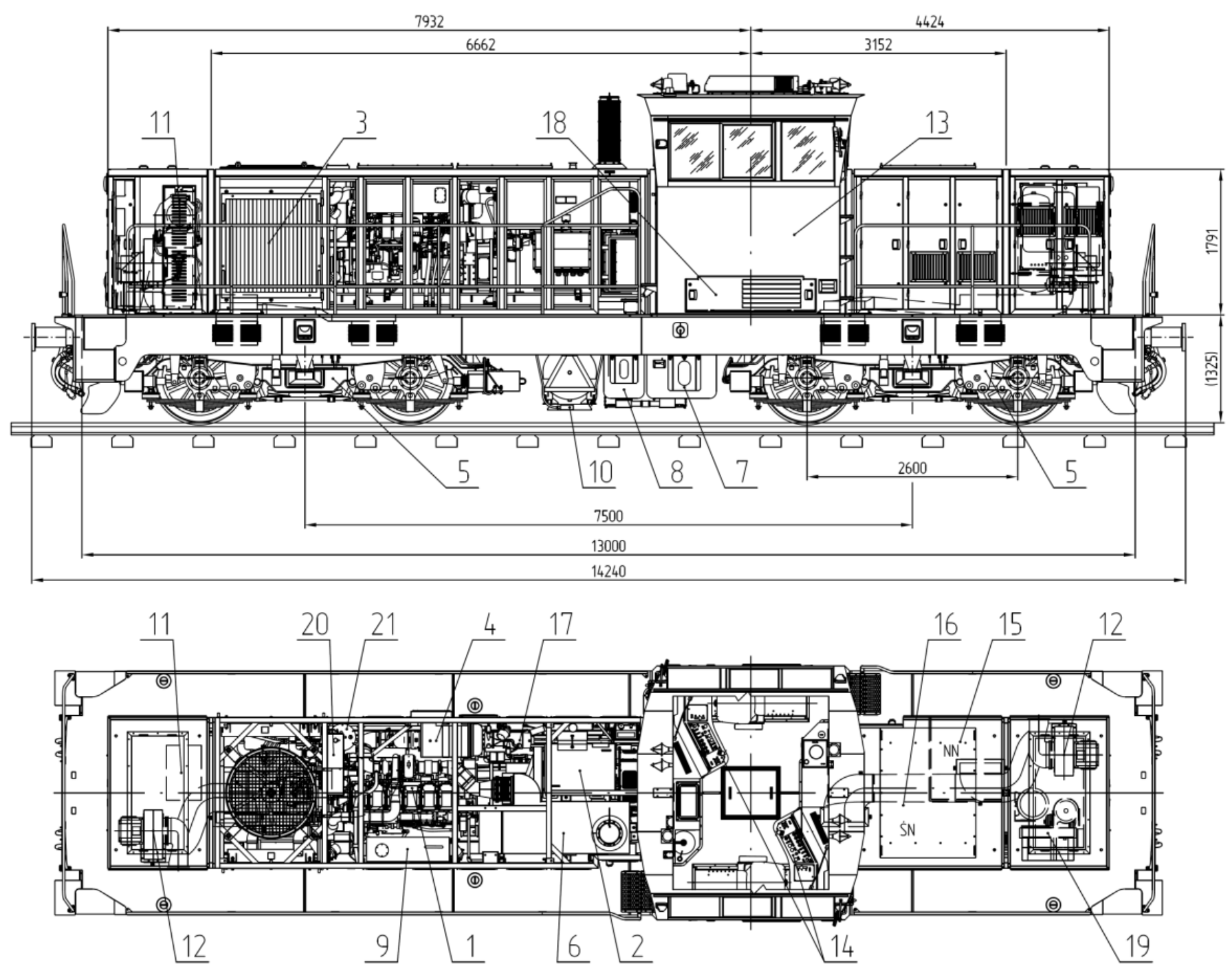

Rys. 2.2. Rozmieszczenie maszyn i urządzeń na lokomotywie spalinowej typu 6Di serii SM42 z silnikiem CAT C27 (1 - silnik spalinowy, 2 - zespół prądnic synchronicznych, 3 - zespół chłodnic / wentylator, 4 - filtr powietrza, 5 - wózek, 6 - thumik wylotu spalin, 7 - zbiorniki paliwa, 8 - elektromagnes, 9 - agregat sprężarkowy, 10 - wentylator silników trakcyjnych, 11 - kabina maszynisty, 12 - pulpity sterownicze, 13 - szafa NN, 14 - szafa SN, 15 - podgrzewacz Webasto, 16 - skrzynia akumulatorów, 17 - tablica pneumatyczna)

Fig. 2.3. Location of systems and devices and basic dimensions of the 6Di locomotive with Cummins engine (1 - combustion engine, 2 - synchronous generator set, 3 - cooler unit/fan, 4 - air filter, 5 - bogie,

6 - exhaust muffler, 7 - main fuel tank, 8 - additional fuel tank, 9 - intermediate fuel tank,

10 - electromagnet, 11 - compressor unit, 12 - traction engine fan, 13 - driver's cab, 14 - control desks, 15 - LV cabinet, 16 -

MV cabinet, 17 - pre-heater, 18 - battery box, 19 - pneumatic panel, 20 - coolant expansion tank, 21 - hydrostatic oil tank).

- control cabin with two independent desks and armchairs, with high thermal and acoustic insulation, panoramic heated windows, external mirrors or cameras, control cabinets, cabinets with SHP and CA generators, and fire control center. The cabin was mounted on rubber and metal shock absorbers, and a cooling system was built on the cab roof

- control and diagnostics system (microprocessor)

- anti-slip system at start-up and braking

- devices related to traffic safety and radio communication

- electronic speedometers and the main locomotive operation parameters recording systems

- halogen outdoor lighting and signal lamps.
- kabina sterownicza z dwoma niezależnymi pulpitami i fotelami, o wysokiej izolacji cieplnej i akustycznej, szybami panoramicznymi ogrzewanymi elektrycznie, lusterkami zewnętrznymi lub kamerami, szafami sterowniczymi, szafami z generatorami SHP i CA oraz centralką p-poż. Kabina została posadowiona na amortyzatorach gumowometalowych, a na dachu kabiny zabudowano schładzacz.

- układ sterowania i diagnostyki (mikroprocesorowy)

- układ przeciwpoślizgowy przy rozruchu i hamowaniu

- urządzenia związane $\mathrm{z}$ bezpieczeństwem ruchu oraz łączności radiowej 
A general view of the selected main locomotive assemblies is shown in Figs 2.4 - 2.7.

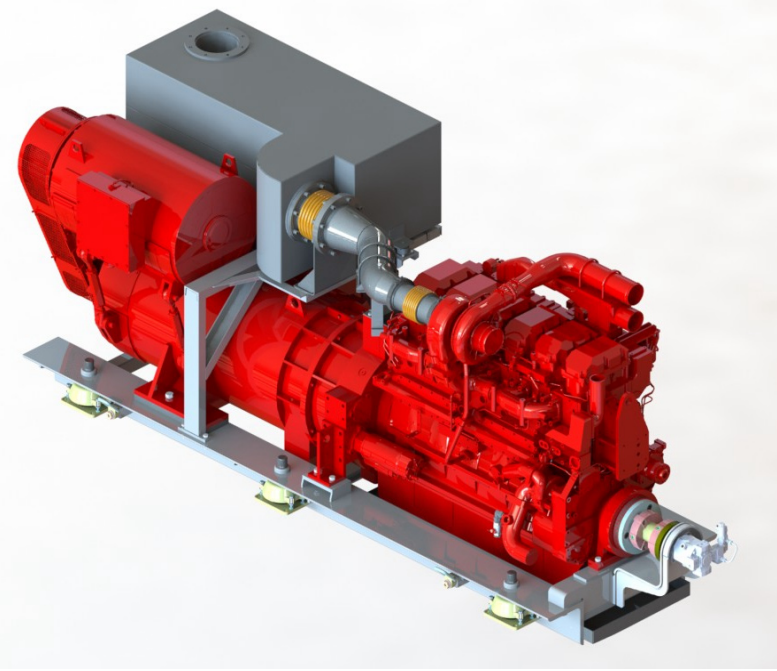

Fig. 2.4. Power generator with the Cummins engine Rys. 2.4. Agregat prądotwórczy z silnikiem Cummins

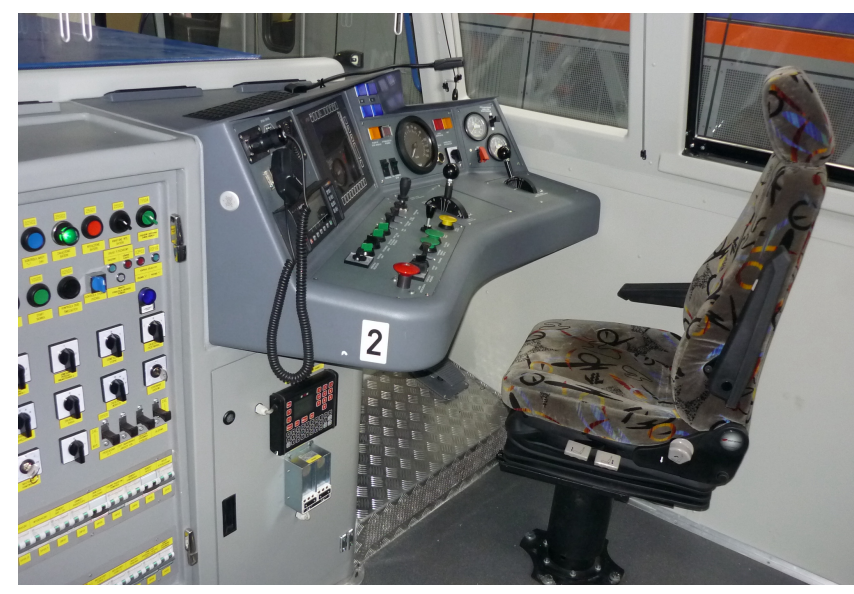

Fig. 2.6. Driver's cab of a modernized 6Di locomotive with a CATERPILLAR engine

Rys. 2.6. Kabina maszynisty zmodernizowanej lokomotywy 6Di z sinikiem CATERPILLAR
- elektroniczne prędkościomierze i rejestratory głównych parametrów pracy lokomotywy

- halogenowe oświetlenie zewnętrzne i lampy sygnałowe.

Widok ogólny na wybrane główne zespoły lokomotywy przedstawiono na rysunkach $2.4-2.7$.

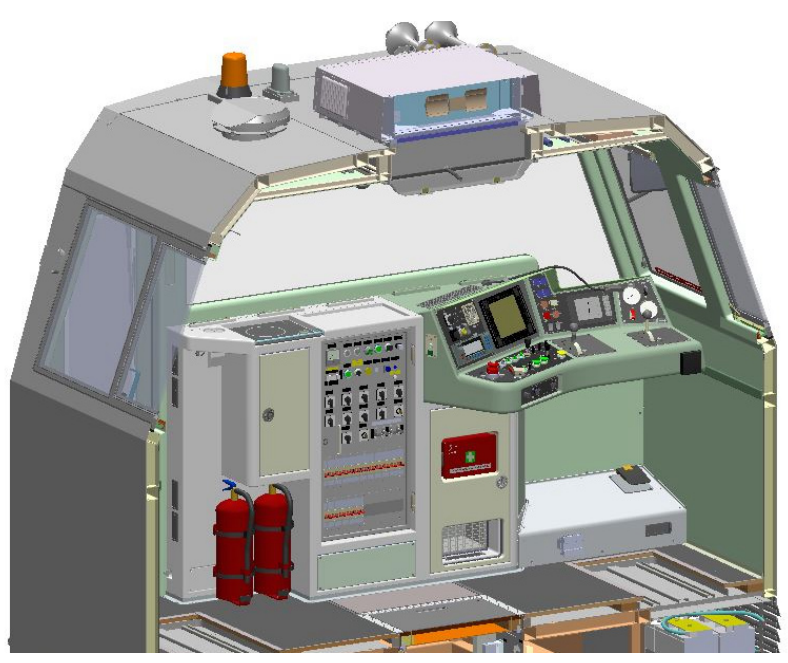

Fig. 2.5. Driver's cabin model of the 6Di locomotive Rys. 2.5. Model kabiny maszynisty lokomotywy 6Di

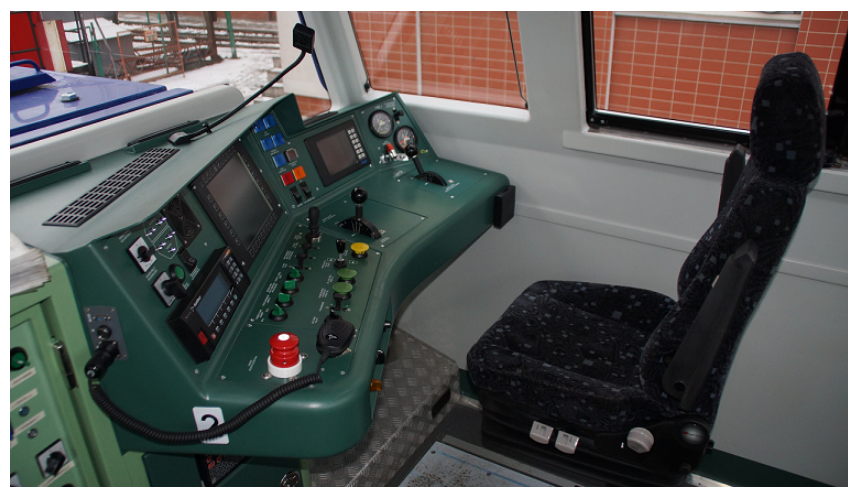

Fig. 2.7. Driver's cab of a modernized 6Di locomotive with a Cummins engine

Rys. 2.7. Kabina maszynisty zmodernizowanej lokomotywy 6Di z sinikiem Cummins

Table 1. Main technical parameters of the 6Di locomotive before and after modernization.

Tablica 1. Glówne parametry techniczne lokomotywy 6Di przed i po modernizacji.

\begin{tabular}{|c|c|c|c|c|c|c|}
\hline 1.p. & \multicolumn{2}{|c|}{ Wielkość, parametr } & Jedn. & \multicolumn{3}{|c|}{ Wartość } \\
\hline 1 & \multicolumn{2}{|c|}{ Producent lok. bazowej } & - & \multicolumn{3}{|c|}{ FABLOK Chrzanów } \\
\hline 2 & \multicolumn{2}{|c|}{ Тур } & - & $\begin{array}{c}\text { 6D (lokomotywa } \\
\text { bazowa) }\end{array}$ & 6Di (CAT) & 6Di (CUMMINS) \\
\hline 3 & \multicolumn{2}{|c|}{ Masa służbowa } & {$[\mathrm{Mg}]$} & 74 & $70,5 \pm 3 \%$ & $72 \pm 3 \%$ \\
\hline 4 & \multicolumn{2}{|c|}{ Prędkość maksymalna } & {$[\mathrm{km} / \mathrm{h}]$} & \multicolumn{3}{|c|}{90} \\
\hline \multirow[t]{2}{*}{5} & \multirow{2}{*}{\multicolumn{2}{|c|}{ Rodzaj przekładni }} & \multirow[t]{2}{*}{-} & elektryczna & elektryczna & elektryczna \\
\hline & & & & $\mathrm{DC} / \mathrm{DC}$ & $\mathrm{AC} / \mathrm{DC}$ & $\mathrm{AC} / \mathrm{DC}$ \\
\hline \multirow[t]{2}{*}{6} & \multirow[t]{2}{*}{ Hamulec } & - zasadniczy & \multirow[t]{2}{*}{ - } & Orlikon & MH & MH \\
\hline & & - postojowy & & mechaniczny & mechaniczny & sprężynowy \\
\hline 7. & Urządzenia & pieczeństwa ruchu & - & - & SHP, CA, RS & SHP, CA, RS \\
\hline
\end{tabular}


c.d. Tabeli 1

\begin{tabular}{|c|c|c|c|c|c|c|}
\hline \multirow[t]{5}{*}{8.} & \multirow{5}{*}{$\begin{array}{c}\text { Silnik } \\
\text { spalinowy }\end{array}$} & - producent & & H.Cegielski & CATERPILLAR & CUMMINS \\
\hline & & - typ & & a8C22 & C27 ACERT & QSK 23 L-900 \\
\hline & & $\begin{array}{l}\text { - moc } \\
\text { znamionowa }\end{array}$ & {$[\mathrm{kW}]$} & 590 & 708 & 671 \\
\hline & & $\begin{array}{l}\text { - obroty } \\
\text { znamionowe }\end{array}$ & {$\left[\mathrm{min}^{-1}\right]$} & 1000 & 1800 & 1800 \\
\hline & & $\begin{array}{l}\text { - emisja } \\
\text { zanieczyszczeń }\end{array}$ & - & - & \multicolumn{2}{|c|}{ EU 26/2004 etap III A } \\
\hline \multirow[t]{3}{*}{9.} & \multirow{3}{*}{$\begin{array}{l}\text { Prądnica } \\
\text { główna }\end{array}$} & - producent & & ZWME Wrocław & \multicolumn{2}{|c|}{ EMIT S.A. Żychlin } \\
\hline & & - typ & & LSPa-740 & Ghp 400 M4C-1 & Ghp 400 M4C-2 \\
\hline & & $\begin{array}{l}\text { - moc } \\
\text { znamionowa } \\
\text { ciagła }\end{array}$ & {$[\mathrm{kW}]$} & 588 & 590 & 590 \\
\hline \multirow[t]{3}{*}{10.} & \multirow{3}{*}{$\begin{array}{l}\text { Prądnica } \\
\text { pomocnicza }\end{array}$} & - producent & & Dolmel Wrocław & \multicolumn{2}{|c|}{ EMIT S.A. Żychlin } \\
\hline & & - typ & & LSPa-280 & \multicolumn{2}{|c|}{ Ghp 315 S4K } \\
\hline & & $-\mathrm{moc}$ & {$[\mathrm{kW}]$} & 10 & 63 & 63 \\
\hline \multirow[t]{3}{*}{11.} & \multirow{3}{*}{$\begin{array}{l}\text { Silniki } \\
\text { trakcyjne }\end{array}$} & - producent & & \multicolumn{3}{|c|}{ Dolmel Wrocław } \\
\hline & & - typ & & \multicolumn{3}{|c|}{ LSa/LSf-430 } \\
\hline & & $-\mathrm{moc}$ & {$[\mathrm{kW}]$} & \multicolumn{3}{|c|}{173} \\
\hline 12. & \multicolumn{2}{|c|}{ Napięcie obw. sterowania } & {$[\mathrm{V}]$} & 110 & \multicolumn{2}{|c|}{24} \\
\hline 13. & \multicolumn{2}{|c|}{ System sterowania } & & elektryczny & \multicolumn{2}{|c|}{ mikroprocesorowy } \\
\hline \multirow[t]{3}{*}{14.} & \multirow{3}{*}{$\begin{array}{l}\text { Sprężarka } \\
\text { powietrza }\end{array}$} & - rodzaj & & tłokowa & \multicolumn{2}{|c|}{ śrubowa } \\
\hline & & - wydajność & $\mathrm{m}^{3} / \mathrm{min}$ & $0,6-3,4$ & \multicolumn{2}{|c|}{1,9} \\
\hline & & - typ & & W2P-315 & \multicolumn{2}{|c|}{ 05SG 01-1 } \\
\hline 15. & \multicolumn{3}{|c|}{ Napęd wentylatora chłodnicy } & wał Kardana & przekładnia pasowa & hydrostatyczny \\
\hline 16. & \multicolumn{3}{|c|}{ Napęd wentylatora silników trakcyjnych } & $\begin{array}{l}\text { silnik elektr. } \\
110 \mathrm{~V} \text { DC }\end{array}$ & \multicolumn{2}{|c|}{$\begin{array}{l}\text { silnik elektr. } \\
3 \times 400 \mathrm{~V} \text { AC }\end{array}$} \\
\hline 17. & & abina maszynisty & & - & \multicolumn{2}{|c|}{$\frac{3 \times 400 \mathrm{~V} \text { AC }}{\text { amortyzowana }}$} \\
\hline 18. & \multicolumn{3}{|c|}{ Stałe urządzenie gaśnicze przedziałów } & - & - & FOGTEC \\
\hline
\end{tabular}

\subsubsection{Di locomotive traction properties}

The modernized 6Di locomotive with the CATERPILLAR engine is characterized by the following basic traction properties:

- starting traction force

$219 \mathrm{kN}$

- continuous pulling force

$112 \mathrm{kN}$

- max. power on the circumference of the wheels

- continuous speed

- multiple traction

$528 \mathrm{~kW}$

$18 \mathrm{~km} / \mathrm{h}$

optional.

The graphs corresponding to these traction parameters are shown in Figs. 2.8 and 2.9.

\section{Locomotive 19D - modernized locomotive of the SM48 series (TEM2 in the industry)}

The 19D diesel locomotive with the Co-Co axle arrangement is primarily intended for heavy shunting operations as well as for heavy freight operations on standard track lines at speeds of up to $100 \mathrm{~km} / \mathrm{h}$. The modernization process was performed for two types of internal combustion engines with the power of $1500 \mathrm{~kW}$ and $1800 \mathrm{~kW}$. As an option the locomotive can be adapted to operate on broad-gauge lines by using the appropriate bogie. In 2017, a 19D locomotive was built with a MTU 12V 4000 R84 engine with a power of $1800 \mathrm{~kW}$. The locomotive was built by PESA Bydgoszcz S.A.

The 19D locomotive project assumed a modular construction, which is why the main locomotive systems, similarly to the 6Di locomotive, were built in

\subsection{Wlasności trakcyjne lokomotywy 6Di}

Zmodernizowana lokomotywa typu 6Di z silnikiem CATERPILLAR charakteryzuje się następującymi podstawowymi właściwościami trakcyjnymi:

- siła pociągowa rozruchowa $219 \mathrm{kN}$

- siła pociagowa ciagła $\quad 112 \mathrm{kN}$

- maks. moc na obwodzie kół $\quad 528 \mathrm{~kW}$

- prędkość ciagła

$18 \mathrm{~km} / \mathrm{h}$ - trakcja wielokrotna opcjonalne. Odpowiadające tym parametrom trakcyjnym są wykresy przedstawione na rysunkach 2.8 i 2.9 .

\section{Lokomotywa 19D - zmodernizowana lokomo- tywa serii SM48 (dla przemysłu TEM2)}

Lokomotywa spalinowa typu 19D o układzie osi Co-Co przeznaczona jest przede wszystkim do ciężkich prac manewrowych i przetokowych oraz prowadzenia ciężkich pociagów towarowych na liniach normalnotorowych z prędkością do $100 \mathrm{~km} / \mathrm{h}$. Proces modernizacji przeprowadzono dla dwóch typów silników spalinowych o mocy $1500 \mathrm{~kW}$ i $1800 \mathrm{~kW}$. Lokomotywa w opcji może zostać przystosowana do ruchu po liniach szerokotorowych przez zastosowanie odpowiedniego wózka. W 2017 roku zbudowano lokomotywę 19D z silnikiem MTU 12V 4000 R84 o mocy $1800 \mathrm{~kW}$. Lokomotywa została zbudowana przez Pojazdy Szynowe PESA Bydgoszcz S.A.

Projekt lokomotyw 19D zakładał budowę modułową, dlatego główne układy lokomotywy podobnie 


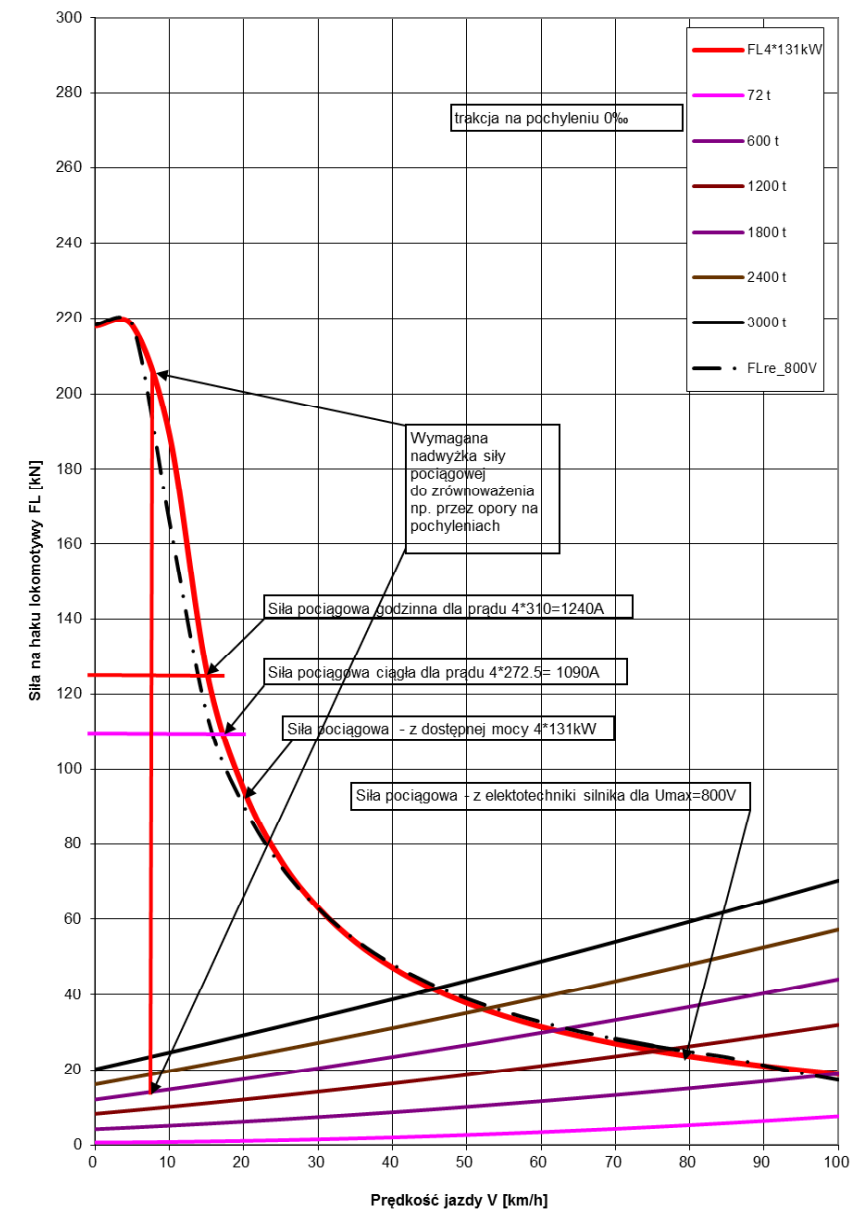

Fig. 2.8. Traction characteristics of the (6Di) SM42 locomotive Rys. 2.8. Charakterystyka pociagowa lokomotywy SM42 (6Di)

self-contained modules adapted for lifting by crane for maintenance and repairs. The exception is the generator set, where the engine with the generator has been mounted on the chassis.

In addition, the following systems were installed on the bogies: fans of traction motors, compressor unit and traction cabinet. The modules have been additionally equipped with dampers and removable roofs, as well as multi-winged doors, which ensured free access to all devices built on the locomotive.

A general view of the layout of systems and devices on the 19D locomotive is shown in Fig. 3.1.

\subsection{The scope of modernization and technical pa- rameters of the 19D locomotive}

As in the case of the 6Di locomotive, the modular design of the 19D locomotive made it possible to improve the production and efficient preparation of construction and technical documentation. In the modernized locomotive, the chassis was preserved without significant changes, which was subjected to the main repair and modifications allowing for the construction of a new body and generator set.

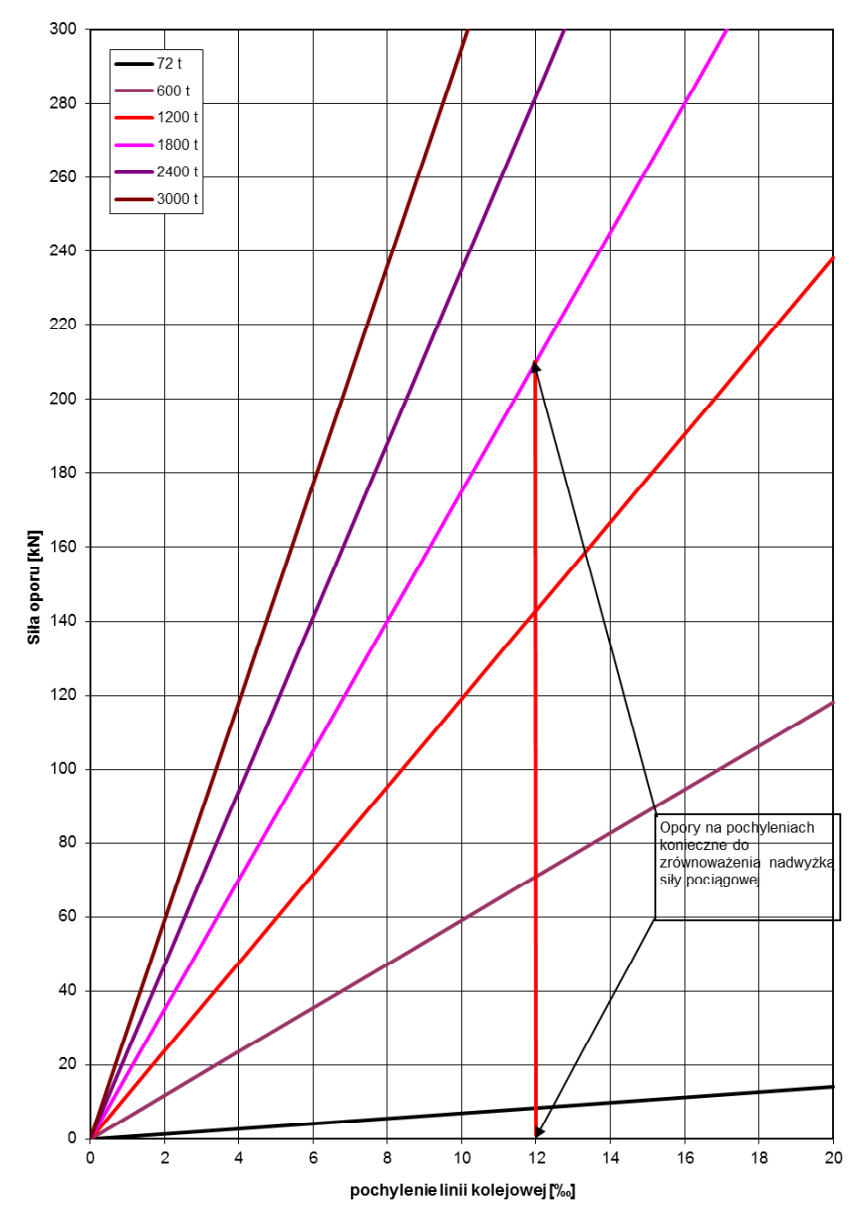

Fig. 2.9. Train friction on sloping tracks

Rys. 2.9. Opory pociągów na liniach pochylonych

jak w lokomotywie 6Di zostały zabudowane w samonośnych modułach przystosowanych do podnoszenia za pomocą suwnicy podczas prac serwisowych i napraw. Wyjątkiem jest przedział agregatu prądotwórczego, gdzie silnik z prądnicą został zamontowany na ostoi.

Ponadto na ostoi zostały zabudowane następujące zespoły: wentylatory silników trakcyjnych, zespół sprężarkowy i szafa trakcyjna. Moduły zostały wyposażone dodatkowo w klapy i dachy odejmowalne a także w drzwi wieloskrzydłowe co pozwoliło zapewnić swobodny dostęp do wszystkich urządzeń zabudowanych na lokomotywie.

Widok ogólny rozplanowania maszyn i urządzeń na lokomotywie 19D przedstawiono na rys. 3.1.

\subsection{Zakres modernizacji i parametry techniczne lokomotywy 19D}

Podobnie jak w przypadku lokomotywy 6Di budowa modułowa lokomotywy 19D pozwoliła na usprawnienie produkcji oraz sprawne przygotowanie dokumentacji konstrukcyjnej i technicznej. W modernizowanej lokomotywie zachowana została bez znaczących zmian ostoja, którą poddano 


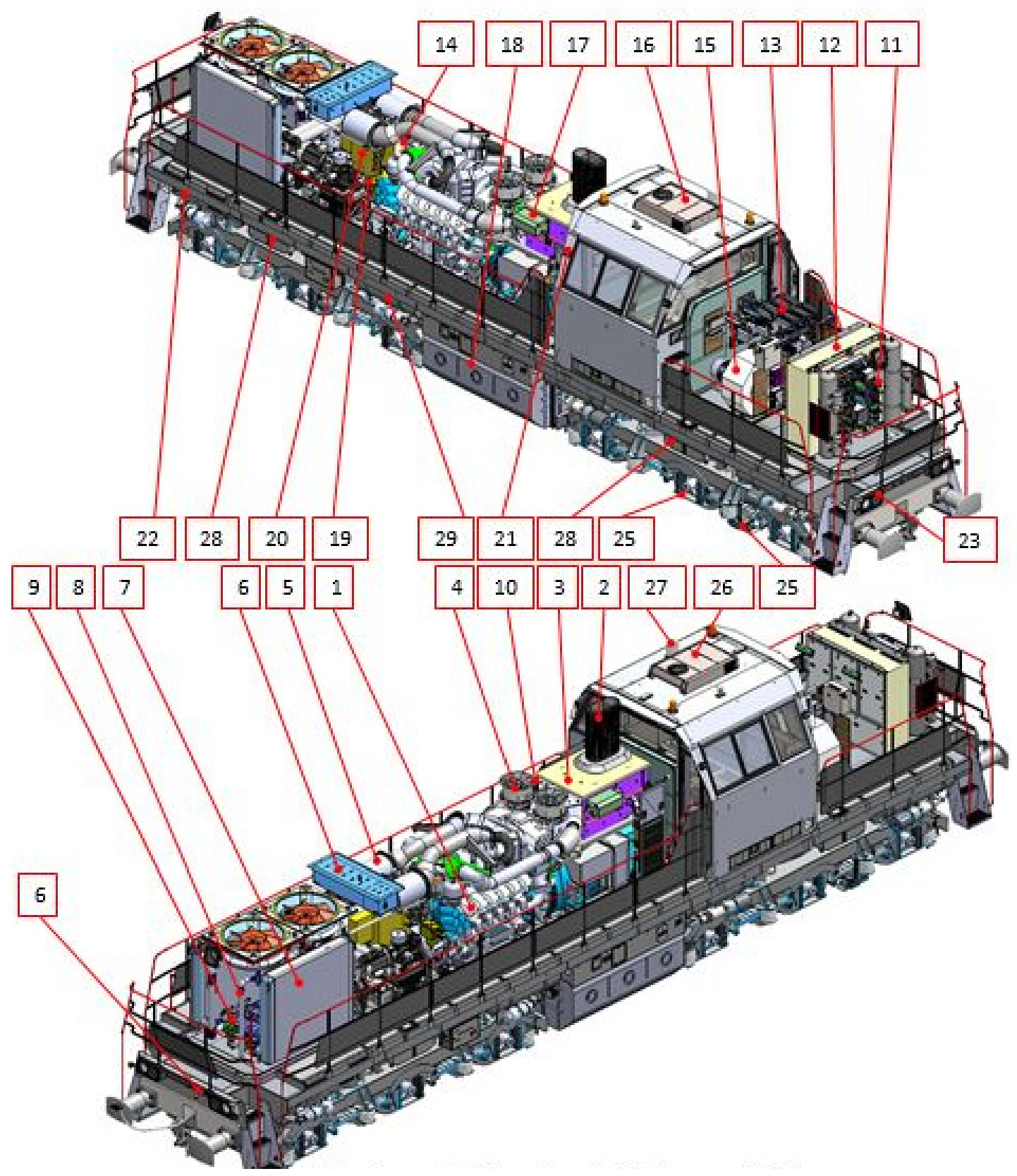

Fig.3.1. Location of main equipment in the 19D locomotive

1-Power generator with MTU internal combustion engine, 2-exhaust muffler with particulate filter, 3-exhaust chimney, 4-fans of machinery compartment and generator set, 5-air intake system for internal combustion engine with air filters, 6-cooling system compensation tank, 7cooling unit, 8-cooling fans of the internal combustion engine, 9-WEBASTO water heaters, 10-REBS system for the lubrication of wheel flanges, 11-pneumatic board and auxiliary air tanks, 12- Lechmotoren converter cabinets, 13-MV and LV cabinet devices, 14-ventilation fan for traction motors - bogie I, 15-ventilation fan for traction motors - bogie II, 16-air-conditioner for driver's cab - cooler, 17-water basins tank, 18-fuel tank, 19 -free fuel filter "SEPAR", 20-air compressor with a filtering system, compressor control system, 21-camera system, 22-lead-acid batteries, 23-halogen and diode headlights, 24-multiple control sockets, 25-SHP electromagnet, 26-GPS antenna, 27-radio antenna, 28-sanding system, 29-main air tanks

Rys. 3.1. Rozmieszczenie głównych urządzeń w lokomotywie 19D

1-Agregat pradotwórczy z silnikiem spalinowym MTU, 2-Tłumik wylotu spalin z filtrem czastek stałych, 3-Komin wylotu spalin, 4Wentylatory przedziału maszynowego - agregatu prądotwórczego, 5-Układ wlotu powietrza do silnika spalinowego z filtrami powietrza, 6Zbiornik wyrównawczy układu chłodzenia silnika spalinowego, 7-Zespół chłodnic, 8-Wentylatory układu chłodzenia silnika spalinowego, 9Podgrzewacze wody WEBASTO, 10-Układ REBS do smarowania obrzeży kół, 11-Tablica pneumatyczna i zbiorniki pomocnicze powietrza, 12-Szafa przetwornic Lechmotoren, 13-Urządzenia szafy SN i NN, 14-Wentylator wentylacji silników trakcyjnych - wózek I, 15-Wentylator wentylacji silników trakcyjnych - wózek II, 16-Klimatyzator kabiny maszynisty - schładzacz, 17-Zbiornik wody umywalki, 18-Zbiornik paliwa, 19-Wstępny filtr paliwa „SEPAR”, 20-Sprężarka powietrza z układem uzdatniania powietrza, układ sterowania sprężarką, 21-Układ kamer zewnętrznych, 22-Akumulatory kwasowe, 23-Reflektory halogenowe i diodowe, 24-Gniazda sterowania wielokrotnego, 25elektromagnesy SHP, 26-Antena GPS, 27-Antena sterowania radiowego, 28-Piasecznice, 29-Główne zbiorniki powietrza 
The main modernized and new systems and devices are:

- MTU 12V 4000 R84 internal combustion engine - the engine meets the Stage IIIB norm according to Directive 2004/26/EC

- generator set - main and auxiliary generator and built-in rectifier

- pneumatic board

- air preparation and filter system with screw compressor driven by an $\mathrm{AC}$ motor

- Autonomous driver's cab with two independent desks and seats, with high thermal and acoustic insulation, electrically heating panoramic windows, cameras replacing mirrors, control cabinets, electric heaters and a roof cooling system. The cabin has been mounted on rubber and metal shock absorbers and equipped with a number of facilities that improve the comfort of drivers, such as a fridge, a hob or a sink.

- control and diagnostics system (microprocessor based produced by IPS TABOR)

- anti-slip system at start-up and braking

- devices related to traffic safety and radio communication

- electronic speedometers and the main locomotive operating parameters recording systems

- permanent fire extinguisher system with aerosols

- modernized brake lever system on the bogie.

A general view of selected main locomotive assemblies is shown in Figs. 3.2 - 3.5 and Table 2.

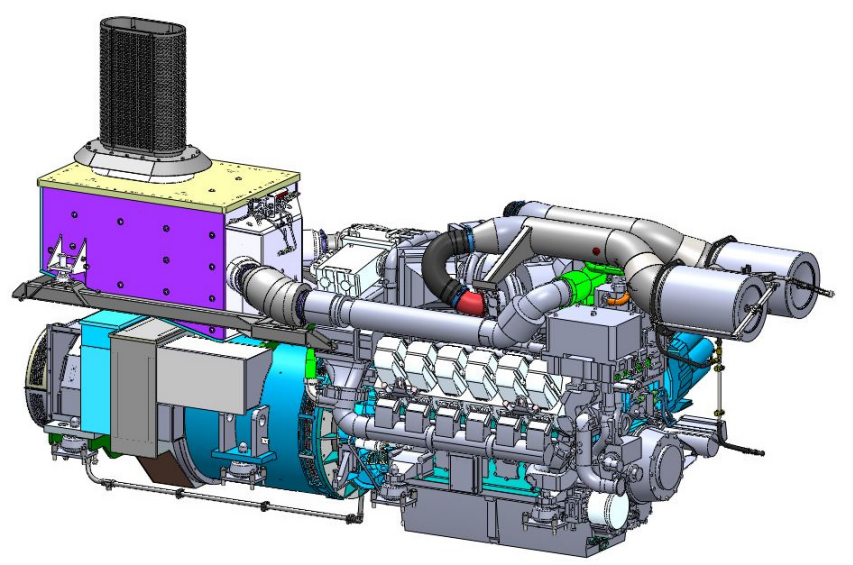

Fig. 3.2. A 19D locomotive generator set Rys. 3.2. Zespół prądotwórczy lokomotywy typu 19D

Fig. 3.3. Driver's cabin of the modernized 19D locomotive (3D model)

Rys. 3.3. Kabina maszynisty zmodernizowanej lokomotywy 19D (model 3D) naprawie głównej i dokonano modyfikacji pozwalających na zabudowę nowego nadwozia i agregatu prądotwórczego.

Główne zmodernizowane i nowe układy oraz urządzenia to:

- silnik spalinowy MTU typu 12V 4000 R84 - silnik spełnia poziom emisji substancji szkodliwych - etap IIIB wg dyrektywy 2004/26/WE

- zespół prądnic - główna z prądnicą pomocniczą $\mathrm{i}$ zabudowanym prostownikiem

- tablica pneumatyczna

- układ przygotowania i uzdatniania powietrza ze sprężarką śrubową napędzaną silnikiem prądu przemiennego

- autonomiczna kabina maszynisty z dwoma niezależnymi pulpitami i fotelami, o wysokiej izolacji cieplnej i akustycznej, szybami panoramicznymi ogrzewanymi elektrycznie, kamerami zastępującymi lusterka, szafami sterowniczymi, nagrzewnicami elektrycznymi i schładzaczem dachowym. Kabina została posadowiona na amortyzatorach gumowo-metalowych oraz wyposażona w szereg udogodnień podnoszących komfort pracy maszynistów takich jak lodówka, płyta grzewcza czy umywalka.

- układ sterowania i diagnostyki (mikroprocesorowy produkcji IPS TABOR)

- układ przeciwpoślizgowy przy rozruchu i hamowaniu

- urządzenia związane z bezpieczeństwem ruchu oraz łączności radiowej

- elektroniczne prędkościomierze i rejestratory głównych parametrów pracy lokomotywy

- system stałej instalacji gaszącej z aerozolami

- zmodernizowany układ dźwigniowy hamulca na wózku.

Widok ogólny na wybrane główne zespoły lokomotywy przedstawiono na rysunkach $3.2-3.5$ i tablicy 2.

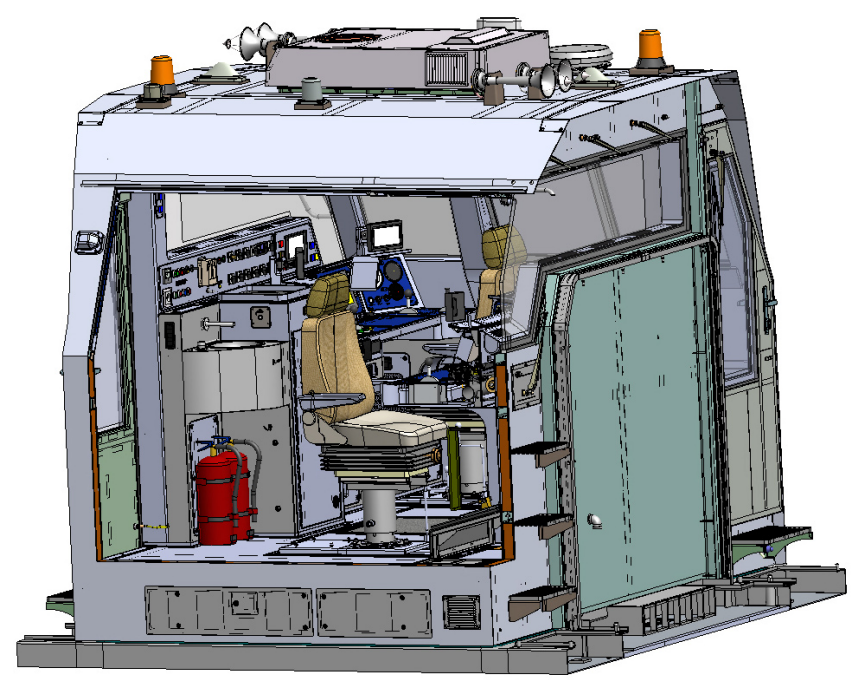




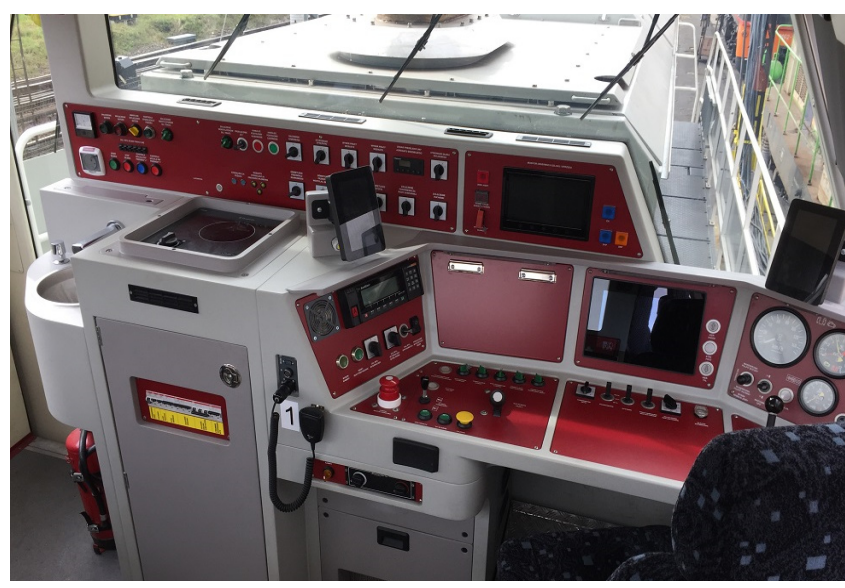

Fig. 3.4. Driver's cab of the modernized 19D locomotive Rys. 3.4. Kabina maszynisty zmodernizowanej lokomotywy 19D

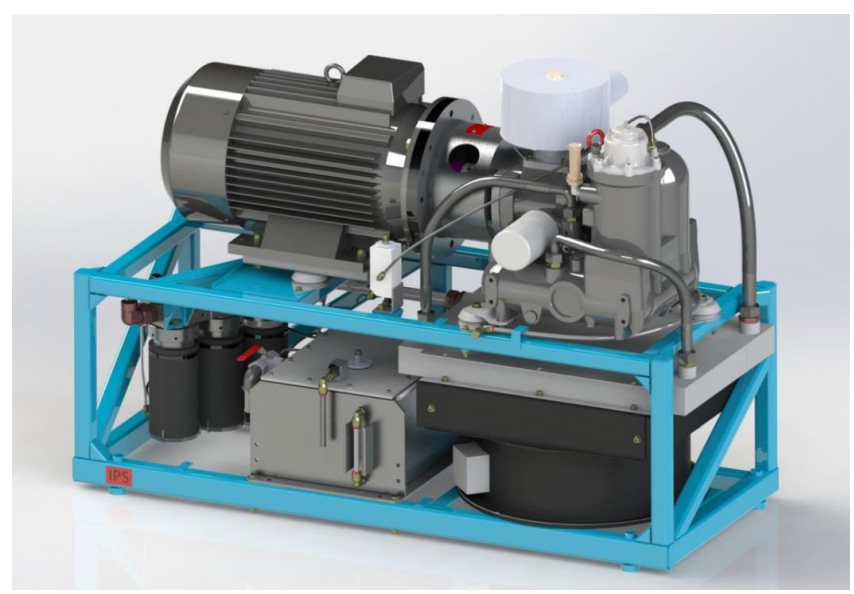

Fig. 3.5. The compressor assembly of the modernized 19D locomotive

Rys. 3.5. Zespół sprężarkowy zmodernizowanej lokomotywy typu 19D

Tablica 2. Główne parametry techniczne lokomotywy 19D przed i po modernizacji

\begin{tabular}{|c|c|c|c|c|c|}
\hline \multirow{2}{*}{ LHo. } & \multirow{2}{*}{\multicolumn{2}{|c|}{ Type, parameter }} & \multirow{2}{*}{ Unit } & \multicolumn{2}{|c|}{ Vahe } \\
\hline & & & & Before modemization & After modemization \\
\hline 1. & \multicolumn{2}{|c|}{ Original locomotive manufacturer } & - & \multicolumn{2}{|c|}{ ZSRR BMZ Briaŕsk } \\
\hline 2. & \multicolumn{2}{|c|}{ Type } & - & TEMD2 & $19 \mathrm{D}$ \\
\hline 3. & \multicolumn{2}{|l|}{ Service mass } & {$[\mathrm{Mg}]$} & \multicolumn{2}{|c|}{$118^{-4 \$}$} \\
\hline 4. & \multicolumn{2}{|l|}{ Maximumspeed } & [km/h] & \multicolumn{2}{|c|}{100} \\
\hline \multirow{2}{*}{5.} & \multirow{2}{*}{\multicolumn{2}{|c|}{ Transsmission type }} & \multirow[b]{2}{*}{ - } & electric & electric \\
\hline & & & & $D C-D C$ & $\mathrm{AC}-\mathrm{DC}$ \\
\hline \multirow{2}{*}{6.} & \multirow{2}{*}{ Brale } & $-\operatorname{mam}$ & \multirow{2}{*}{ - } & Matrosow & $\mathrm{MH}$ \\
\hline & & - parking & & & spring \\
\hline 7. & \multirow{8}{*}{$\begin{array}{l}\text { Traffic safety devices } \\
\text { Internal combustion } \\
\text { engine: }\end{array}$} & & - & mone & SHP, CA, RS \\
\hline \multirow{7}{*}{8.} & & - marnufacturer & - & ZSRR & MTU \\
\hline & & - type & - & PDIM & $12 \mathrm{~V} 4000 \mathrm{R} 84$ \\
\hline & & - rated power & {$[\mathrm{kW}]$} & 83 & 1800 \\
\hline & & - engine speed & {$\left[\mathrm{min}^{-1}\right]$} & 750 & 1800 \\
\hline & & - exhaust emission & - & no data & $\begin{array}{l}\text { EU 25:2004 } \\
\text { Stage III B }\end{array}$ \\
\hline & & - fuel comsurmption & $g / \mathrm{kWh}$ & 229 & $202^{+3 \%}$ \\
\hline & & - oil consmption & $g / \mathrm{kWh}$ & no data & $02 \%$ fuel oonsmrqtion \\
\hline \multirow{3}{*}{99.} & \multirow{3}{*}{ Main generator } & - maruffacturer & \multirow[b]{3}{*}[\mathrm{kW}]{} & \multirow{3}{*}{$\begin{array}{c}\text { ZSRR } \\
\text { GP-300BU2 } \\
780\end{array}$} & \multirow{3}{*}{$\begin{array}{c}\text { Lechmotoren. } \\
\text { New altemating cment } \\
\text { generator with rectifier } 1800\end{array}$} \\
\hline & & - type & & & \\
\hline & & - orntrinious power & & & \\
\hline 110. & Auxiliary generabr & - marufacturer & - & $\begin{array}{c}\text { ZSRR } \\
\text { MWG-25MU2 } 2 \\
5.75 \mathrm{~kW}\end{array}$ & $\begin{array}{c}\text { Lechmotoren. } \\
\text { Wew altemating cment } \\
\text { generator with rectifier } 120 \\
\text { kVA }\end{array}$ \\
\hline \multirow{2}{*}{111.} & \multirow{2}{*}{ Traction motos } & - type & - & \multicolumn{2}{|c|}{ ED $118 \mathrm{AU} 2$} \\
\hline & & - continuous power & $\mathrm{kW}$ & 105 & $\sim 240$ \\
\hline 112. & \multicolumn{2}{|c|}{ Control cimuits voltage } & {$[\mathrm{V}]$} & 75 & 24 \\
\hline 113. & \multicolumn{2}{|c|}{ Control system } & - & electric & migopnocessor \\
\hline \multirow{2}{*}{114.} & Aircon=ment. & - type, power & & $\begin{array}{l}\text { piston, from the } \\
\text { crankshaft. }\end{array}$ & $\begin{array}{c}\text { screw, } \\
\text { electric motor, } 3 \times 400 \mathrm{~V}_{A C,}, 22\end{array}$ \\
\hline & Air compressor: & - effriency & $\mathrm{m}^{4} \mathrm{~mm}$ & 46 & $\begin{array}{l}\mathrm{kW} \\
29\end{array}$ \\
\hline 115. & Radiator fan drive & & - & Cardan shaft & $\begin{array}{l}\text { lydrostatic - smooth speed } \\
\text { control }\end{array}$ \\
\hline 116. & Traction motors fanc & nive & - & belt tranamissiom & electric motor $3 \times 400 \mathrm{~V}_{A C}$ \\
\hline 117. & Driver's cabin & & - & & $\begin{array}{l}\text { new equipment that meets } \\
\text { current requirements of } \\
\text { ergonomics and work safety }\end{array}$ \\
\hline 118. & Fixed compartmentfi & re extingurishing devive & - & mone & AEROSOL GENERAOTR \\
\hline
\end{tabular}


Table 2. Main technical parameters of the 19D locomotive before and after modernization

\begin{tabular}{|c|c|c|c|c|c|}
\hline \multirow[b]{2}{*}{ No. } & \multirow{2}{*}{\multicolumn{2}{|c|}{ Type parameter }} & \multirow{2}{*}{ Unit } & \multicolumn{2}{|r|}{ Vabue } \\
\hline & & & & Before modemization & After modemization \\
\hline 1. & \multicolumn{2}{|c|}{ Original locomotive manufacturer } & - & \multicolumn{2}{|c|}{ ZSRR BMZ Briaŕsk } \\
\hline 2. & \multicolumn{2}{|c|}{ Type } & - & TEML2 & 19D \\
\hline 3. & \multicolumn{2}{|l|}{ Service mass } & {$[\mathrm{Mg}]$} & \multicolumn{2}{|r|}{$118^{-5 / 5}$} \\
\hline 4. & \multicolumn{2}{|l|}{ Maximumspeed } & [m/h] & \multicolumn{2}{|r|}{100} \\
\hline \multirow{2}{*}{5.} & \multirow{2}{*}{\multicolumn{2}{|c|}{ Transmission type }} & \multirow{2}{*}{ - } & electric & electric \\
\hline & & & & $\mathrm{DC}-\mathrm{DC}$ & $\mathrm{AC}-\mathrm{DC}$ \\
\hline \multirow{2}{*}{6.} & \multirow{2}{*}{ Brake } & $-\operatorname{mam}$ & \multirow{2}{*}{-} & Matrosow & $\mathrm{MH}$ \\
\hline & & - parking & & & sprimg \\
\hline 7. & Traffic safety devices & & - & mone & SHP, CA, RS \\
\hline \multirow{7}{*}{8.} & \multirow{7}{*}{$\begin{array}{l}\text { Internal combustion } \\
\text { engine: }\end{array}$} & - marnufacturer & - & ZSRR & MTU \\
\hline & & - type & - & PDIM & $12 \mathrm{~V} 4000 \mathrm{R} 84$ \\
\hline & & - rated power & {$[\mathrm{kW}]$} & 883 & 1800 \\
\hline & & - engine sped & {$\left[\min ^{-1}\right]$} & 750 & 1800 \\
\hline & & - exhanst emission & - & no data & $\begin{array}{l}\text { EU 25:2004 } \\
\text { Stage III B }\end{array}$ \\
\hline & & - fuel consurntion & $g / \mathrm{kWh}$ & 229 & $202^{+3 \%}$ \\
\hline & & - oil consumption & $g / \mathrm{kWh}$ & no data & $02 \%$ fuel oonsmmtion \\
\hline \multirow[b]{3}{*}{9.} & \multirow{3}{*}{ Main generator } & - maruffacturer & \multirow[b]{3}{*}[\mathrm{kW}]{} & \multirow{3}{*}{$\begin{array}{c}\text { ZSRR } \\
\text { GP-300BU2 } \\
780\end{array}$} & \multirow{3}{*}{$\begin{array}{l}\text { Lechmotoren. } \\
\text { New altemating cument gen- } \\
\text { erator with rectifier } 1800\end{array}$} \\
\hline & & - type & & & \\
\hline & & - oontirnous power & & & \\
\hline 10. & Auxiliary generabr & - maroufacturer & - & $\begin{array}{c}\text { ZSRR } \\
\text { MWG-25IIU2 } \\
5.75 \mathrm{~kW}\end{array}$ & $\begin{array}{l}\text { Lechomotoren. } \\
\text { New altemating cur- } \\
\text { rert generatorwith rectifier } \\
120 \mathrm{kVA} \\
\end{array}$ \\
\hline \multirow[b]{2}{*}{11.} & \multirow{2}{*}{ Traction mobs } & - type & - & \multicolumn{2}{|r|}{ ED 118 AU2 } \\
\hline & & - oontrinouss power & $\mathrm{kW}$ & 105 & $\sim 240$ \\
\hline 12. & \multicolumn{2}{|c|}{ Control cimuits voltage } & {$[\mathrm{V}]$} & 75 & 24 \\
\hline 13. & \multicolumn{2}{|l|}{ Control system } & - & electric & migoprocessor \\
\hline \multirow[b]{2}{*}{14.} & Aircom=nenr. & - type, power & - & $\begin{array}{l}\text { pitor, from the crank- } \\
\text { shaft. }\end{array}$ & $\begin{array}{c}\text { screw, } \\
\text { electric motor, } 3 \times 400 \mathrm{~V}_{A C}, 22\end{array}$ \\
\hline & Air compressor: & - effriency & $\mathrm{m}^{4} \mathrm{~mm}$ & 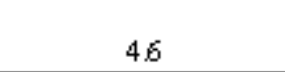 & $\begin{array}{l}\mathrm{kW} \\
29\end{array}$ \\
\hline 15. & Radiator fan drive & & - & Cardan shaft & $\begin{array}{l}\text { hyrdrostatic - smooth } \\
\text { speed oortol }\end{array}$ \\
\hline 16. & Traction motos fan & rive & - & belt tranamission & electric motor $3 \times 400 \mathrm{~V}_{A C}$ \\
\hline 17. & Driver's cabin & & - & & $\begin{array}{l}\text { new equipment that meets } \\
\text { current requirements of ergo- } \\
\text { nomirs and wonk safety }\end{array}$ \\
\hline 18. & Fixed compartmentfi & re extinguishing device & - & more & $\begin{array}{l}\text { AEROSOL GEN- } \\
\text { ERAOTR }\end{array}$ \\
\hline
\end{tabular}

\subsubsection{D locomotive traction properties}

The modernized 19D locomotive is characterized by the following basic traction properties:

- starting traction force $455 \mathrm{kN}$

- continuous pulling force

- max. power on the circumference of the wheels $1350 \mathrm{~kW}$

- continuous speed

- multiple traction $40 \mathrm{~km} / \mathrm{h}$ optional.

The graphs corresponding to these traction parameters are shown in Figs. 3.6 and 3.7.

\subsection{Wlasności trakcyjne lokomotywy 19D}

Zmodernizowana lokomotywa typu 19D charakteryzuje się następującymi podstawowymi właściwościami trakcyjnymi:

- siła pociagowa rozruchowa $455 \mathrm{kN}$

- siła pociagowa ciagła

- maks. moc na obwodzie kół $1350 \mathrm{~kW}$

- prędkość ciagła. $40 \mathrm{~km} / \mathrm{h}$

- trakcja wielokrotna opcjonalne.

Odpowiadające powyższym parametrom trakcyjnym wykresy przedstawiono na rysunkach 3.6 i 3.7. 


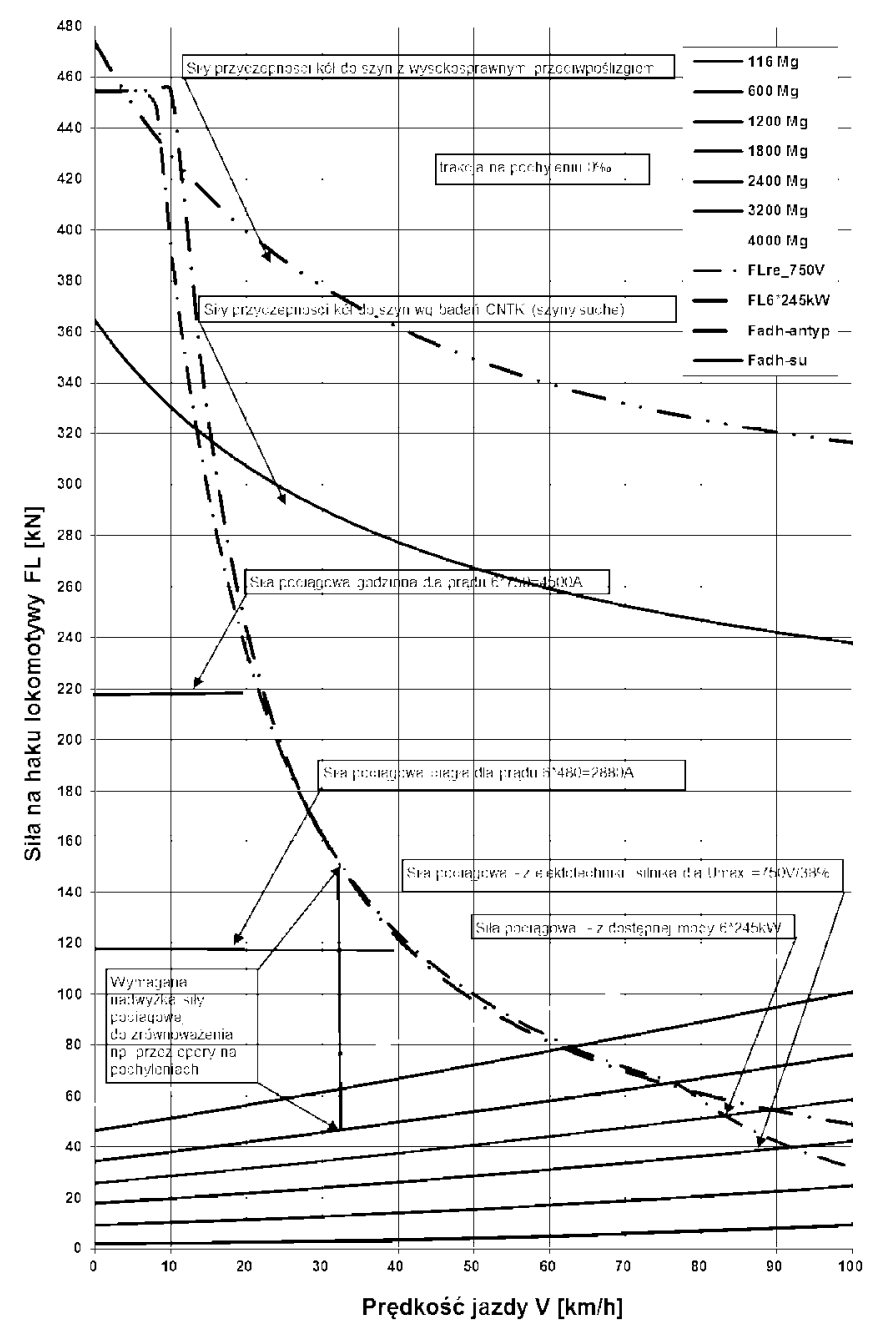

Fig. 3.6. Traction characteristics of 19D type locomotive

Rys. 3.6. Charakterystyka pociaggowa lokomotywy typu 19D

\section{Conclusions}

The described 6Di and 19D locomotives are examples of modernization in which modern systems and assemblies were used and projects in a $3 \mathrm{D}$ environment were developed, which allowed to reduce production costs. After modernization the locomotives have reached the parameters of new vehicles with extended service intervals and high reliability.

6Di locomotives have been approved for use on base of the certificate, while the 19D type locomotive has been approved for placing in service a type of railway vehicle.

The modernized locomotives have been shipped to the rail operators where they successfully carry out their assigned transport operations.

Unfortunately, all of the analyzed locomotives have been modernized as single units and therefore it should be stated that the greatest benefits from modernized 6Di and 19D locomotives could be achieved only by expanding the modernization process to a greater number of vehicles.

Hence it is obviously necessary to modernize the operated diesel locomotives done through both, purchasing new and modernizing existing locomotives in or-

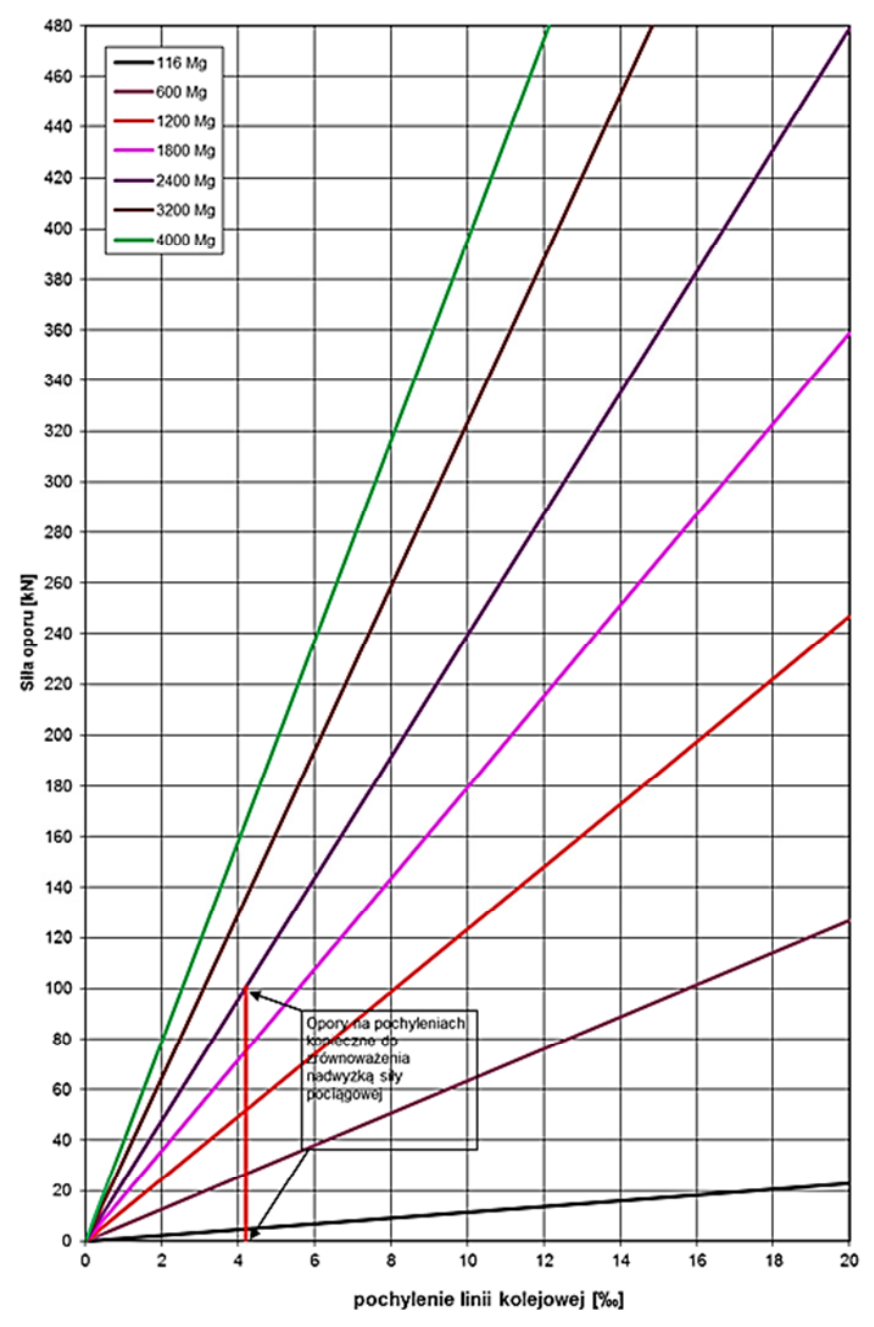

Fig. 3.7. Motion resistance of train on sloping tracks

Rys. 3.7. Opory pociągów na liniach pochylonych

\section{Podsumowanie}

Opisane lokomotywy typu 6Di i 19D są przykładami modernizacji, w których wykorzystano nowoczesne układy i zespoły oraz opracowano projekty w środowisku 3D, co pozwoliło na ograniczenie kosztów przy produkcji. Lokomotywy po modernizacji zyskały cechy nowych pojazdów $\mathrm{z}$ wydłużonymi okresami międzyprzeglądowymi oraz wysoką niezawodnością.

Lokomotywy typu 6Di uzyskały dopuszczenie do eksploatacji na podstawie świadectwa, natomiast lokomotywa typu 19D uzyskała zezwolenie na dopuszczenie do eksploatacji dla typu pojazdu kolejowego.

Lokomotywy oddane zostały do służby u przewoźników, gdzie z powodzeniem wykonują przypisane im prace transportowe.

Niestety wszystkie opisane powyżej lokomotywy zostały wykonane w jednym egzemplarzu i dlatego należy stwierdzić, że największe korzyści ze zmodernizowanych lokomotyw 6Di i 19D osiagnięte zostaną tylko w przypadku wdrożenia do eksploatacji większej ich liczby.

Podsumowując, oczywista jest konieczność unowocześniania parku lokomotyw spalinowych realizowana przez zakupy nowych oraz przez modernizację ist- 
der to continuously raise the technical level of the rolling stock and increase their safety of operation as well as the comfort of drivers and service.

Pictures of modernized 6Di and 19D locomotives are shown below.

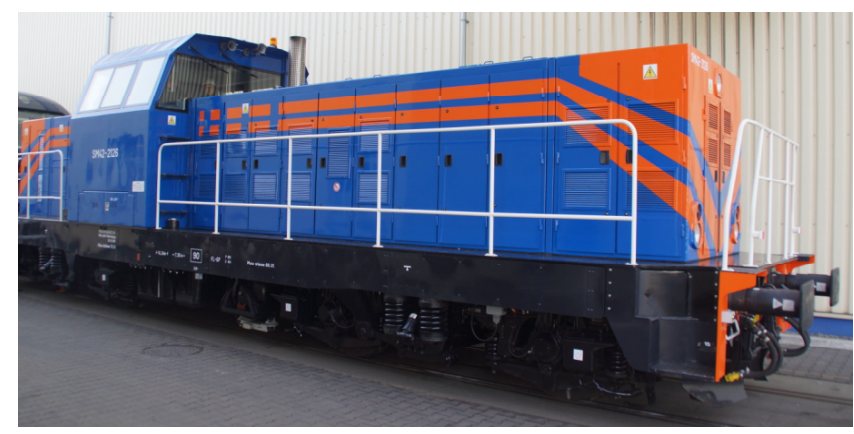

Fig. 4.1. Picture of the modernized 6Di locomotive with the CATERPILLAR engine

Rys. 4.1. Widok zmodernizowanej lokomotywy 6Di z silnikiem CATERPILLAR

\section{Bibliography / Literatura}

1. Marciniak Z.: Przeglad modernizacji lokomotyw spalinowych w Polsce., Poznań 2016

2. Michalak P., Jakuszko W., Czerwiński J: Projekt lokomotywy 19D jako podstawa wersja platformy zmodernizowanych lokomotyw serii SM48 i ST44. IV Międzynarodowa Konferencja Naukowa ,najnowsze technologie w transporcie szynowym., Józefów $k$. Warsza$w y-2015 r$.

3. Czerwiński J., Dobrowolski P., Jakuszko W., Michalak P.: Możliwości zmiany istotnych dla środowiska parametrów eksploatacyjnych spalinowych lokomotyw 6osiowych przez modernizację zespołów. Pojazdy Szynowe, $2015 \mathrm{nr} 4$.

4. Marciniak Z.: Projekty modernizacyjne spalinowych lokomotyw liniowych $i$ manewrowych wykonanych $w$ Instytucie Pojazdów Szynowych. Logistyka, $2010 \mathrm{nr} 4$.

5. Czerwiński J., Dobrowolski P., Jakuszko W., Michalak P.: Możliwości zmiany istotnych dla środowiska parametrów eksploatacyjnych spalinowych lokomotyw 6osiowych przez modernizacje zespołów. Pojazdy Szynowe, $2015 \mathrm{nr} 4$.

6. Czerwiński J., Jakuszko W., Michalak P.: Proces projektowania zmodernizowanej lokomotywy 19D. Pojazdy Szynowe, $2016 \mathrm{nr} 3$.

7. Michalak P., Jakuszko W.: Nowe rozwiazania i uktady w modernizowanej lokomotywie spalinowej typu $19 \mathrm{D}$ serii SM48 zwiększajqce niezawodność i bezpieczeństwo w eksploatacji. VIII Międzynarodowa Konferencja Naukowo-Techniczna, ,Systemy Logistyczne Teoria i Praktyka", Warszawa 2015 r.

8. Miklasz R., Antkowiak T., Michalak P.: Modernizacja wózków lokomotywy 19D w kierunku zmniejszenia częstości obstugi eksploatacyjnej. IV Międzynarodowa Konferencja Naukowa ,najnowsze technologie $w$ transporcie szynowym., Józefów k. Warszawy - 2015r. niejących lokomotyw w celu ciagłego podnoszenia poziomu technicznego taboru i podnoszenia bezpieczeństwa eksploatacji, a także komfortu pracy maszynistów i serwisu.

Poniżej przedstawiono zdjęcia zmodernizowanych lokomotyw typu 6Di i 19D.

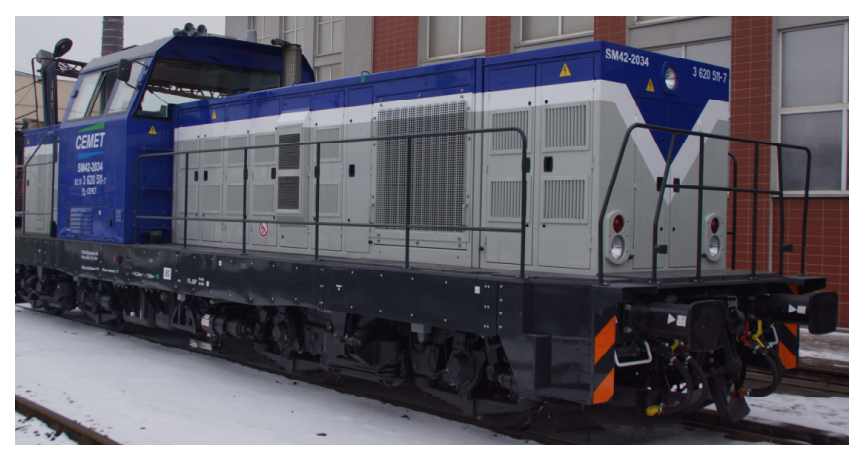

Fig. 4.2. Picture of the modernized 6Di locomotive with the CUMMINS engine

Rys. 4.2. Widok zmodernizowanej lokomotywy 6Di z silnikiem CUMMINS

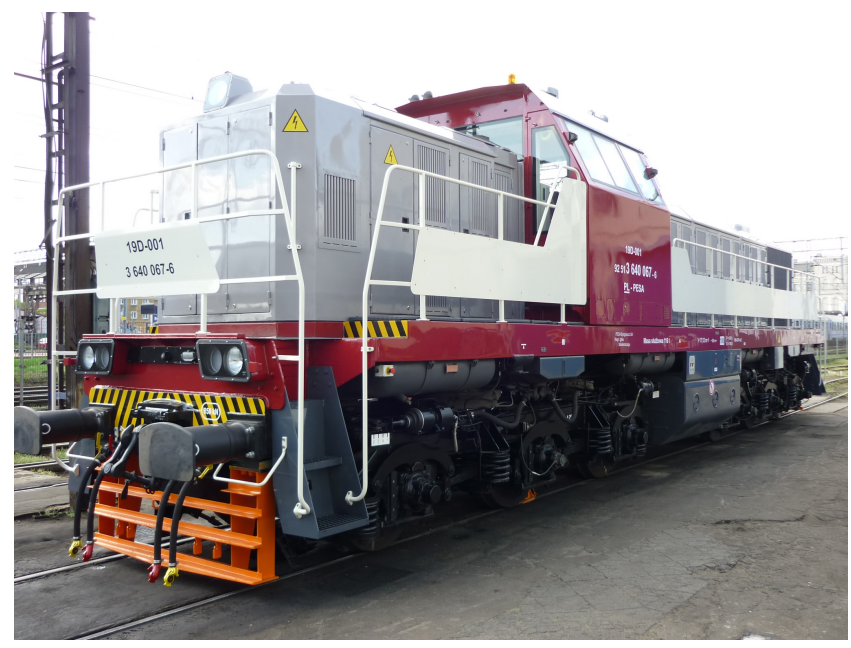

Fig. 4.3. Picture of the modernized 19D locomotive with the MTU engine

Rys. 4.3. Widok zmodernizowanej lokomotywy 19D z silnikiem MTU

9. Marciniak Z.: Projekty modernizacyjne spalinowych lokomotyw liniowych $i$ manewrowych wykonanych $w$ Instytucie Pojazdów Szynowych, Logistyka, $2010 \mathrm{nr} 4$.

10. Marciniak Z., Jakuszko W., Michalak P.: Nowe układy $i$ rozwiazania techniczne $w$ modernizowanej lokomotywie serii SM 42 typu 6Di. Pojazdy Szynowe, $2013 \mathrm{nr} 1$.

11. Czerwiński J., Marciniak Z.: Modułowe konstrukcje jedno- $i$ dwukabinowych lokomotyw elektrycznych $i$ spalinowych. Pojazdy Szynowe, 2014 nr 1.

12. Instytut Pojazdów Szynowych ,,TABOR” w Poznaniu Opracowania własne. 